\title{
FORGOTTEN INTERLUDE: EURHYTHMIC DANCERS AT THE PARIS OPÉRA \\ Lynn Garafola
}

Late in the summer of 1917, Jacques Rouché, the director of the Académie Nationale de Musique et de Danse, better known as the Paris Opéra, sent a letter to dancers of the ballet troupe. Did they, he asked, care to take class in the eurhythmics section he was about to establish or would they rather study with their usual teacher, the former ballerina Rosita Mauri, who conducted the class of perfection? Although the file copy of Rouché's letter seems to have disappeared, a number of responses to it have survived at the Archives Nationales in Paris. ${ }^{1}$ Letters from dancers tend to be rare, and this group, amounting to some twenty items, is especially valuable because it deals with an episode that is little known even among scholars of the period. Moreover, because this episode occurred at the start of a modernization process that in time transformed every aspect of ballet at the Opéra, the teaching practices alluded to in some of the letters suggest reasons for the deteriorating performance standard that led many to dismiss the company as second-rate.

Jacques Rouché, who served as director of the Opéra from 1915 to $1944,{ }^{2}$ was already a familiar figure in Paris theatre circles at the time of his appointment. Born in 1862, he began his career as a diplomat, worked in the perfume business, and in 1907 became editor of $L a$ Grande Revue, an intellectual journal with extensive coverage of the performing arts and a roster of regular and sometime contributors that included M.-D. Calvocoressi, Camille Mauclair, Jacques Copeau, Henri Matisse, Emile Jaques-Dalcroze, André Dunoyer de Segonzac, and Louis Laloy (who wrote not only about music and opera, but also about dance). ${ }^{3}$ Although Rouché had dabbled in theatre production as early as the 1890 s, it was only in the years prior to the First World War that it became his life's work. By then, he had become fascinated by the new theatre movement that throughout Europe was challenging both the aesthetics of naturalism and the conventions of nineteenth-century stagecraft. Rouchés interest in theatrical developments outside France, which he investigated on 
a study journey that took him to Germany, Italy, and Russia, prompted his only extended piece of writing, the magnificent volume L'Art théâtral moderne. ${ }^{4}$ First published in 1910, the year that he assumed direction of the Théâtre des Arts, the book laid out the theoretical principles underlying the innovative approaches that he now sought to put into practice in the several dozen plays, operas, and ballets mounted by the new venture. His efforts were rewarded: between 1910 and 1913, when he accepted the Opéra appointment, the Thêâtre des Arts won high praise for the imagination of its programming, the taste and artistic quality of its productions, and the talented young artists many of whom would go on to distinguished careers at the Opéra and elsewhere - enlisted as collaborators. An important episode in the history of early twentieth-century French theatre, the enterprise was a laboratory for Rouché's later activities at the Opéra.

Unlike Lugné-Poe's Théâtre de l'Oeuvre, which staged some of the earliest French productions of Henrik Ibsen, Maurice Maeterlinck, August Strindberg, Maxim Gorky, Emile Verhaeren, and other modern playwrights, Rouché's enterprise offered not only dramatic works - the French premiere of George Bernard Shaw's Mrs. Warren's Profession (1912), Jacques Copeau's adaptation of The Brothers Karamazov (1911), Henri Ghéon's 'popular tragedy' Le Pain (1911), Saint-Georges de Bouhelier's Le Carnaval des Enfants (1910) - but also works of lyric theatre that stood outside the tradition of French 'grand opera.' Some of these came from the eighteenth-century repertoire - Jean-Philippe Rameau's operaballets Les Fêtes d'Hébé (1911) and Pygmalion (1913), for example. Others, like Jacques Offenbach's one-act operetta Mesdames de la Halle (1913), Léo Delibes's opéra-bouffe Les Deux vieilles gardes (1912), and Emmanuel Chabrier's Une Education manquée (1913), although of more recent vintage, had long ceased to be performed. Still others, including Maurice Ravel's Ma Mère l'Oye (1912), were newly minted.

To design these works, Rouché called upon a group of French painters, including Maxime Dethomas, Drésa, and René Piot, who had contributed in various ways to $L a$ Grande Revue. None had worked previously for the stage: Piot, for instance, was best known for his frescoes. ${ }^{5}$ Modernist in orientation, all three artists would follow Rouché to the Opéra, where they would significantly 
contribute to the new look of postwar productions. Design, in fact, played a key role in Rouché's earliest reform efforts. 'At that time,' he later told an interviewer referring to his tenure at the Théâtre des Arts, 'I was rather keen on returning the theatre to the painter, without, however, giving him the dominant role. . . . Already I was seeking a way to fuse the arts without distorting them, to combine and enrich them.' ${ }^{6}$ The collaboration of nonspecialist stage painters, announced a reviewer for Comoedia illustré, 'decidedly marks a new tendency in France, which Monsieur Jacques Rouché has encouraged and supported with success. ${ }^{7}$

However new in terms of French theatre, Rouchés approach to design was clearly indebted to the fusionist ideology and postsymbolist aesthetic of the Ballets Russes. His interest in dance, especially new dance, also owed a debt to the Russian enterprise, even if in France (unlike Italy), ballet had remained an integral part of opera throughout the second half of the nineteenth century. Under his aegis the Théâtre des Arts gave unusual prominence to dance, which was featured not only in lyric works like Pygmalion and Les Fêtes d'Hébé, but also in plays like Louis Laloy's Le Chagrin dans le Palais de Han (1912), an adaptation of MaTcheu-Yuen's fourteenth-century Chinese drama, and Molière's comedy-ballet Le Sicilien, ou l'Amour peintre (1919), with music by Jean-Baptiste Lully. Rouché also produced a number of fullfledged ballets, including Laloy's Les Folies françaises, ou les Dominos (1911), to music by François Couperin, and Dolly (1913), to music by Gabriel Fauré; Catulle Mendès's L'Amoureuse Lȩ̧on (1913), to music by Alfred Bruneau; Gilbert de Voisins's Le Festin de l'Araignée (1913), to a score by Albert Roussel; and Ravel's Ma Mere l'Oye, adapted by the composer from his original piano suite. It was Rouché, too, who organized at the Théâtre du Châtelet in 1912 the dance concert starring Natalia Trouhanova that offered premieres of Paul Dukas's La Péri and Ravel's Adélaide, ou le Langage des fleurs (based on the 'Valses nobles et sentimentales' with an argument by the composer), in addition to reprises of Vincent d'Indy's Istar and Florent Schmitt's La Tragédie de Salomé - all of which Rouché would later produce at the Opéra.'

Apart from the Trouhanova works, which were choreographed by the former Bolshoi ballet master Ivan Clustine, and Ma Mere l'Oye, which was staged by Jane Hugard, ' the dances in these productions were entrusted to Léo Staats, another Théâtre des Arts 
alumnus who would follow or, more correctly, return with Rouché to the Opéra. Staats had studied at the Opéra school under Louis Mérante, graduating into the company in 1893, the same year he choreographed his first ballet, Ici l'on danse. In 1908, when André Messager and L. Broussan assumed the management of the Opéra, Staats was appointed ballet master, producing during his two-year tenure new versions of Namouna (1908) and Javotte (1909). ${ }^{10}$ With the reopening of the Opéra late in 1915 (it had closed at the beginning of World War I), he returned to the house, both as a choreographer and, after a stint in the army, as its principal ballet master, a post he held from 1919 to 1926.

The dancers who worked under Staats at the Théâtre des Arts were an eclectic group. In Le Festin de l'Araignée, for instance, the mantises were played by the clowns Tommy and Georgey Footitt, while the spider was played by the exotic Sahary-Djeli, a music hall celebrity and sometime Salomé known for her extreme suppleness. ${ }^{11}$ Similarly, in Nabuchodonosor (1911), a drama with musical interludes, the role of the Young Dancer was performed by Trouhanova, a soloist who specialized in exotic and 'Greek' styles (although she did not disdain to don pointe shoes on occasion). Although several of the dancers had studied with Staats (like most Opéra ballet masters of the time, he gave private classes in addition to teaching at the Opéra) and although at least two of them (including the future premier danseur Albert Aveline ${ }^{12}$ ) were members of the Opéra troupe, most lacked the well-rounded training of the professional ballet dancer. Caryathis, the nom de théatre of Elise Toulemon, who later published several volumes of reminiscence under her married name, Elise Jouhandeau, was one such student. Having run away from home and settled in Montmartre, she announced to her friends that she intended to be a dancer. One of them took her to the studio where Staats gave private classes to the Opéra's 'grands sujets. ${ }^{\text {'13 }}$ Although she was only a beginner, Staats agreed to teach her.

Before long, however, she discovered Jean d'Udine, a 'dissident apostle' (in André Levinson's phrase) ${ }^{14}$ of the Dalcroze system, whose Ecole Française de Rythme, located on the Avenue de Ternes, attracted pupils such as Comtesse Etienne de Beaumont and Rouché's own daughters, one of whom, Madame BarbeyRouché, later became the director of the most important Dalcroze school in Paris. ${ }^{15}$ D'Udine's method, Caryathis later wrote, 'was of 
great help to me in creating my musical interpretations,' an allusion to the choreographic career that began at the Theâtre des Arts, where, at the urging of Staats himself, she composed the first of her own dances -the 'red dance' before the emperor in $L e$ Chagrin dans le Palais de Han. ${ }^{16}$ Pleased with her performance, Staats introduced her to Ravel and gave her the role of the Serpentin Vert in Ma Mere l'Oye. It was only after these experiences, if her memoirs are to be believed, that Caryathis discovered 'the Attic art ... and poetry of perfection' of Isadora Duncan and presented her first recital. ${ }^{17}$

After auditioning unsuccessfully for a character dance position at the Opéra in 1915 (a move that her lover, actor Charles Dullin, strongly opposed and probably worked behind the scenes to defeat), ${ }^{18}$ Caryathis appeared in ballets by Debussy and Florent Schmitt and in 1919 in the 'Fête nègre' organized by the art dealer Paul Guillaume and the poet Blaise Cendrars at the Comédie des Champs-Elysées. ${ }^{19}$ She choreographed erotic dances (with titles like Bacchanale, Dionysienne, Volupte) ${ }^{20}$ Spanish-style dances, ${ }^{21}$ and in 1921, at the Théâtre Colisée, the dances to Satie's 'La Belle Excentrique ${ }^{22}$ - offerings that in their use of parody and jazz anticipated, according to Levinson, works such as Les Biches and Against the Quota, a production of the Ballets Suédois. ${ }^{23}$ She also appeared in Francis Picabia's 1924 New Year's Eve spectacular, Ciné-Sketch, at the Thêatre des Champs-Elysées, along with Marcel Duchamp, Jean Borlin, and the entire Ballets Suédois company. ${ }^{24}$

Caryathis was not the only dancer at the Théatre des Arts influenced by various currents of the era's new dance. Her close friend, Ariane Hugon, although a member of the Opéra company, had fallen under the spell of the Greeks: photographs show her prancing in tunics and sandals with the pliant upper body of early Ballets Russes dancers. Hugon did not actually reject the technique of the danse d'ecole. She approved, for instance, of its limbering and stamina-building exercises and its method for inculcating the art of harmonious gesture. But she believed in instinct and 'beautiful emotions,' and in dances with titles like Vision antique she presented herself to the public as a Duncan-style dancer, even while remaining on the Opéra payroll and performing featured roles in several Théâtre des Arts productions. ${ }^{25}$

Djemil-Anik was another Théâtre des Arts dancer with an 
unconventional background who, like Caryathis, went on to a career as a soloist. Born in Martinique of mixed race, ${ }^{26}$ Djemil was the Good Fairy in Ma Mere l'Oye and one of the dancers in Le Chagrin dans le Palais de Han. She boasted many friends among the avant-garde, including the painter Kees Van Dongen, who arranged for her to dance at Guillaume's 'Fête nègre,' where, according to Baron Mollet, Apollinaire's former secretary, she appeared 'completely nude and painted from head to feet' by the artist himself. ${ }^{27}$ Unlike Caryathis, who specialized in ironic vignettes to contemporary music, Djemil made her mark as an exotic dancer. At a 1922 concert at the Comédie Montaigne that Levinson reviewed, she performed an 'Egyptian triptych,' in addition to Javanese, Japanese, and Chinese dances. ${ }^{28}$ Later recitals added Indian, African, and West Indian numbers to this repertoire - a tour de monde worthy of Ruth St. Denis and her American progeny. ${ }^{29}$

However interesting some of the Théâtre des Arts dancers may have been as individuals, the company as a whole left much to be desired. In a letter written in 1911 after attending a performance of the Ballet Russes, René Piot, who had no qualms about speaking his mind, complained to Rouché about the 'cows' [veaux] - a favorite word of his - 'imposed on us by Staats. ${ }^{30}$ In another letter, the artist refused to apologize for an outbreak of temper inspired by the 'disorderly habits' of the troupe, which no one, apparently, was able to control:

I reacted with anger because these women are such cows that someone has to make them understand what they are, and the language I used was the only one they understand. Obviously, I do not speak of your little actresses, who are very nice, or of dancers like Anik or Zourna, who are fine: but Staats has given us real shits [des excréments]. ${ }^{31}$

Piot complained that the dancers failed to appear for rehearsals, ruined his costumes by sitting on the skirts, chattered in the wings during performances - behavior that he contrasted with the exemplary discipline of the Ballets Russes, which he had visited backstage with designer Léon Bakst. ${ }^{32}$ On one occasion, he advised Rouché to contact an agency in Milan for dancers. 'You can find ... what you want for as little as 70 francs a month!! ... The school of Milan, although based on old principles, is perhaps the best in the world. Technically, their dancers appear to be of the first order. ${ }^{33}$ On another occasion, he asked whether he could 


\section{FORGOTTEN INTERLUDE}

replace Staat's 'sluts' [roulures] with dancers engaged by designer Maxime Dethomas. On still another, he mentioned to Rouché one Mademoiselle Negri, ${ }^{34}$ who had a small troupe that performed at private gatherings. 'If you take her as première danseuse, you could perhaps ask for her dancers, if they are good. In any case, they can't be worse than what Staats gets us. ${ }^{\prime 35}$ Obviously, neither Rouché nor his close advisors had a clue as to what should be done to form a disciplined dance unit, although all were agreed upon its necessity and the need for it to be modern, whatever this might mean.

As the first decade of Rouché's tenure as Opéra director would prove, being modern meant many things. It prompted him, for instance, to engage the Ballets Russes in 1919, 1920, and 1922, ${ }^{36}$ and Loie Fuller and her company in 1920 and 1923. It led him to invite Michel Fokine to stage Daphnis and Chloé in 1921 and Bronislava Nijinska to choreograph Les Rencontres in 1925; Ida Rubinstein to appear in La Tragédie de Salomé in 1919 and Anna Pavlova to dance La Péri in 1921. The same impulse prompted him to revive eighteenth-century opéra-ballets like Rameau's Castor and Pollux (1918) and Lully's Le Triomphe de l'Amour (1925); to stage ballets like Les Abeilles (1917), to music by Igor Stravinsky, and Adélaïde, ou le Langage des fleurs (1917), to music by Ravel, composers new to the Opéra; to produce Enrique Granados's opera Las Goyescas with the Spanish dancer Amalia Molina (1919); and to present a troupe of real Cambodian dancers in 1922. It prompted him to hold open auditions in 1916 for character and 'plastique,' or expressive dancers to augment the existing in-house company ${ }^{37}$ and, in 1917, to appoint Nicolà Guerra, a respected Italian choreographer and teacher, as its ballet master. And, finally, it led him, again in 1917, to establish a full-fledged eurhythmics department under the direction of Jane Erb, a Dalcroze instructor who had taught the method in Switzerland and was on the staff of the oldest 'official' Dalcroze school in Paris, the Ecole de Rythmique. ${ }^{38}$ As Rouché wrote in an article published after the Second World War, on assuming his post as director of the Opéra, he had a 'strong desire' to institute both a system of primary education on the Russian model and a 'Dalcroze class in rhythmic solfege.' The latter, he added, was inspired by his observations at Hellerau, which he had visited either in 1913 or $1914 .{ }^{39}$ 
From the start, the class was a source of contention. Although poets like Paul Claudel and composers like Arthur Honegger may have shared Rouché's enthusiasm for the Dalcroze system, ${ }^{40}$ which received extensive coverage in the post-Armistice press, ${ }^{41}$ devotees of the 'old ballet' were openly hostile to it. As Léandre Vaillat wrote in his Ballets de l'Opéra de Paris, 'the conflict was no longer between the Italian school and the French school, nor between the French and the Russian schools, but between the academic and the eurhythmic. ${ }^{42}$ Not unexpectedly, few of the dancers queried by Rouché were willing to abandon the 'traditions of the house' that had bred them. ${ }^{43}$ As he later wrote: 'Unfortunately, dancers ... count time in their own way, which is not that of the composer; indifferent to the sequence of sounds, they seek, in the paradoxical formula of Serge Lifar, an extra-musical dance musicality. ${ }^{, 44}$ Still, some of the dancers did express an interest in expanding their horizons, in 'keeping up,' as soloist Olga Soutzo put it, 'with the new methods advocated' by Rouché. She, for one, asked to be enrolled 'in the school of rhythmic dance,' in addition to taking three or more classes a week with 'Mademoiselle Mauri.' 45

A much admired étoile who had danced at the Opéra from 1878 to 1898 , the Spanish-born Mauri was well equipped to pass on the traditions of the house. Trained in France and 'finished' at La Scala, she created the ballerina roles in Louis Mérante's ballets $L a$ Korrigane (1880) and Les Deux Pigeons (1886), his divertissement for Jules Massenet's opera Le Cid (1885), and Joseph Hansen's ballet La Maladetta (1893). Her repertoire also included the title roles in Mérante's Sylvia and Yedda, ballets created for Rita Sangalli in 1876 and 1879, respectively. As Yvonette in La Korrigane, wrote François Coppée, the ballet's composer, Mauri was 'dancing personified':

To the trials of rehearsal... [she] brought a kind of physical enthusiasm, a kind of joyous delirium. You felt that she loved to dance for nothing, from instinct, for the love of dancing, even in a dark and empty theatre. She whinnied and darted like a young foal; she soared and glided in space like a wild bird; and, in her sombre and somewhat wild beauty, there is something of both the Arab steed and the swallow. ${ }^{46}$

After retiring from the stage, Mauri remained at the Opéra, where she taught the class of perfection. However, her conduct of this class, at least by the mid-1910s, was anything but satisfactory. 
Although most of the dancers chose to continue studying with her (the classes, after all, were free), several were sharply critical of her teaching methods. Wrote Jeanine Laugier:

I have just received your letter asking whether I plan to attend the Mauri dance class at the Opéra; I respond as you ask; yes, Monsieur, I will take my lessons as in the past, that is, on a regular basis. But I must point out to you that we cannot continue the classes as they are given by Mademoiselle Mauri, who no longer gives us the same hours as before the war or works with us on the repertoire that you program.

I am sorry to have to write you this, but Mademoiselle Mauri takes us only from 10:30 to 11:20; there is no longer time for all of us to work. Moreover, she has ceased to rehearse the variations we have to perform. ${ }^{47}$

At fifty minutes, the class was little more than a warm-up.

Camille Bos, a soloist promoted to premiere danseuse in 1920, not only reiterated Laugier's criticisms, but also threatened to withdraw from Mauri's classes unless Rouché took action to improve them:

In response to your letter I cannot tell you my intentions on the choice of a teacher.

I hesitate to work with Mademoiselle Mauri, and if the lessons ressemble those of last year, that is, if she does not work with us on our variations for the repertoire, I shall be forced to look for another teacher.

Consequently, I count on you, Mr. Director, to do what is necessary with Mademoiselle Mauri in order to do what is best for our common interests. ${ }^{48}$

Jeanne Schwarz, another soloist, went even further than Bos: she flatly refused to work with Mauri, her teacher of eight years:

In response to your letter ... on the subject of lessons, I have the pleasure of advising you that I will not be attending Mademoiselle Mauri's class.

If this class were really a class of perfection, I would make it my duty to attend, but lessons like these, which I have had for the past eight years, I prefer not to take. ${ }^{49}$

In 1920, Mauri finally retired, and the class of perfection passed to Carlotta Zambelli, the Opéra's much esteemed étoile.

Not all the dancers were as conscientious as this group of letter writers. In the aftermath of the 1920 strike, when Rouché was forced to make sharp cuts in personnel, he drew up a list of expendable artists, with information based partly on their answers to an earlier questionnaire..$^{50}$ Of the twenty-five dancers who were 
dismissed, all but one (a coryphée) were in the lowest ranks for the corps de ballet, and the nature of their infractions, coupled with the fact that more than half the group had passed the age of thirty, indicates that poor teaching alone did not account for the company's sorry state. Discipline was at low ebb. None of the dancers attended class on a daily basis; some, in fact, never went to class at all. Many came late to rehearsals, or even skipped them; others missed entire performances. Some returned weeks late from holiday, spoke insolently to superiors, refused to obey instructions, forgot their entrances, disrupted rehearsals, created disturbances in the wings and onstage. One was continually drunk. Another was pregnant. To Rouché the company must have seemed ungovernable.

Morale, too, was low. For many dancers, a job at the Opéra was just that, a way of making a living, of supporting the children and the sick and elderly parents whose existence depended on their relatives' income. And what an income: 275 to 400 francs a month, L'Humanité reported on the eve of the strike that closed down the Opéra in January 1920 - a 'derisory' sum. ${ }^{51}$ Moreover, for those in the second quadrille, the company's lowest rank, ${ }^{52}$ there was little chance for advancement. Most had entered the company at fourteen or fifteen (although some were actually as young as eleven or twelve), which meant that their training was rudimentary: a turn or two on pointe, an entrechat quatre were all they were expected to do. ${ }^{53}$ Promotion came quickly or not at all. By the age of twenty, if a dancer was still in the quadrille, her career was effectively over. For such dancers, the 'decor props' of the company in Jane Hugard's phrase, ${ }^{54}$ there was nothing to do except bide their time until retirement. Unsurprisingly, many did as little as possible in the interim.

By comparison with this jaded, semi-skilled proletariat, Rouché's newcomers were models of professional pride. They came to the Opéra not as petits rats deposited at the school by their mothers, but as adults committed to careers as artists. Much to the chagrin of traditionalists like Vaillat, eurhythmic dancers were cast in most of the Opéra's new productions of the late 1910s and early 1920s. These included operas like Castor et Pollux (1918), Ernest Reyer's Salammbô (1919), Antoine Mariotte's Salomé (1919), Vincent d'Indy's La Légende de Saint Christophe (1920); Francesco Malipiero's Sept chansons (1920), Hector Berlioz's Les 
Troyens (1921), Gabriel Dupont's Antar (1921), Massenet's Hérodiade (1921), Giuseppe Verdi's Falstaff (1922), Massenet's Grisélidis (1922), his Esclarmonde (1923), Albert Roussel's Padmâvatî (1923), Charles Tournemire's Les Dieux sont morts (1924), Alexandre Georges's Miarka (1925), and André Bloch's Brocéliande (1925), as well as dance works such as La Tragédie de Salomé (1919), Maïmouna (1921), Petite Suite (1922), Artémis troublée (1922), Fresques (1923), Concerto (1923), and Istar (1924). ${ }^{55}$

Obviously, no account of the Opéra in these years can fail to take account of the much disparaged eurhythmic section. Its dancers turned up nearly everywhere, even in ballets like Sylvia and Les Deux Pigeons, the most traditional of the Opéra's dance offerings, where 'crossover dancers' - of whom more later performed the roles of Diane and the Queen of the Gypsies. In less traditional works, classical and eurhythmic dancers often shared the boards, although only occasionally, to judge from the programs, did they appear in the same numbers. Thus, in Castor et Pollux, the divertissements were performed by classical dancers (led by ballerina Aïda Boni), while the Furies and Demons in Act III were played by eurhythmic dancers (led by Yvonne Daunt). In Hérodiade, the divertissements were again danced by classicists, as opposed to the Sacred Dance, which was interpreted by 'eurhythmicians.' In Antar, the two 'schools' were similarly juxtaposed, with ballerina Camille Bos and a classical corps of 'flowers' symbolizing the refreshments of the oasis, and Daunt embodying the thirst of the desert. To traditionalists like Vaillat, this division of labor suggested anything but parity. Referring to Ida Rubinstein, who headed the mixed casts of La Tragédie de Salomé, Artémis troublee, and Istar, he wrote that her presence alone 'confirmed the triumph of la rythmique. ${ }^{56}$

Like the casts, choreographic assignments were sometimes shared. In Les Troyens, the divertissement in Scene 6 was by Staats, while 'La Chasse royale' in Scene 5 was by Rachel Pasmanik, an early Dalcroze follower and prize-winning student at the Conservatory of Geneva, ${ }^{57}$ and Jessmin Howarth, a graduate of the Dalcroze school in London and a former instructor at the New York Dalcroze School. ${ }^{58}$ The same troika also shared the choreography of Hérodiade. Whatever Staats may have thought privately of his eurhythmic colleagues, publicly he accepted their collaboration with grace: as a veteran of the Théâtre des Arts and of 
numerous music hall engagements, he had worked closely with artists of many different backgrounds and performance styles. Indeed, in Sept chansons, Miarka, and Brocéliande, nearly all his dancers came from the Opéra's eurhythmic section. Nicolà Guerra, by contrast, refused point blank to share choreographic duties with Jane Erb, that section's original head. 'I have just learned,' he wrote in outrage to Rouché in 1918, 'that you have assigned Act II of Castor et Pollux, that is, the dances for the demons and the furies, to the teacher of the eurhythmic school. If this is true and if you remain of the same mind, allow me, Mr. Director, to state in all frankness that I withdrew as of now from the composition of this work. ${ }^{59}$ Despite the ballet master's threats, Rouché stood his ground: Erb stayed on the production, as did Guerra.

Sometimes, too, eurhythmic works appeared on the same bill with classical ones. In 1922, when Rouché organized a season of French ballet and scheduled the first all-dance nights presented at the Opéra in decades, the two 'schools' figured pretty much equally on the bills. ${ }^{60}$ Thus, on 11 July 1922, the second night of the 'French' season, he offered Sylvia (with Zambelli in the title role), Artémis troublée (featuring Ida Rubinstein), and Petite suite (1922), a work to Debussy choreographed by Pasmanik and Howarth; ${ }^{61}$ the following night, Namouna , 'La Chasse royale' from Les Troyens, La Péri, and La Maladetta (in a new version by Staats starring Zambelli and Jeanne Schwarz); ${ }^{62}$ a few nights later, Maimouna, Artémis troublée, and 'La Chasse royale'; 63 a week or so after that, La Tragédie de Salomé, Artémis troublée, and Sylvia. Other works presented in the course of the season were Coppélia, the ballet from Charles Gounod's opera Roméo et Fuliette, Fokine's Daphnis and Chloé, Staats's Frivolant (1922), and his extremely popular Taglioni chez Musette (1920). Obviously, the nationality of the composer had more to do with identifying a ballet as French than the nationality of either the dancers or the choreographers. ${ }^{64}$

Castor et Pollux appears to have been Erb's only contribution to the Opéra repertoire. Pasmanik and Howarth were more prolific: in addition to choreographing Petite Suite, they supplied the dances for at least three operas: Les Troyens, Hérodiade, and Falstaff. Clara Brooke, a Dalcroze disciple who had taught at Hellerau and in the United States and participated in the Dalcroze demonstrations at the Salle Gaveau in $1920,{ }^{65}$ was another woman 
from the eurhythmic section who choreographed for the Opéra in these years: her credits included the operas Esclarmonde and Les Dieux sont morts. The only male choreographer among the 'eurhythmic sisterhood' (to borrow a phrase from René Piot) ${ }^{66}$ was Plácido de Montoliu, a Spaniard from Barcelona who had taught at the Dalcroze Center in Hellerau and, beginning in 1913, in various cities of the United States. ${ }^{67}$ According to Vaillat, Montoliu conducted the eurhythmic section's 'class of perfection' (a term, needless to say, that Vaillat employs with irony). Presumably, this was during the 1922-1923 season, when Montoliu choreographed the 'Dance of the Spirits' in Act II of Grisélidis (dismissed by Vaillat as 'a trifle') and two dance works: Fresques and Concerto ${ }^{68}$ With the possible exception of Howarth, none of these choreographers appears to have performed at the Opéra.

In fact, apart from the names of the productions they choreographed, the tenure of these choreographers at the Palais Garnier is a mystery. How they worked, what they taught, why they were hired in the first place - on these and other questions the literature is silent. The few authors who mention the episode at all do so only to rue that it came to an end (the view of Dalcroze biographer Irwin Spector) or that it was undertaken at all (the case of Opéra historian Ivor Guest). ${ }^{69} \mathrm{~A}$ rare glimpse into the eurhythmic studio comes from P. J. S. Richardson, the editor of The Dancing Times, who visited one of Howarth's classes on a tour of the Opéra in 1921:

I had a peep at Miss Howart's [sic] Rhythmic Class, where the Dalcroze Eurhythmics are taught. Here I saw about half a dozen girls-some 'grands sujets,' others merely 'petits sujets'-moving round the room, keeping perhaps common time with their feet, whilst their arms beat triple time, and their bodies softly swayed from side to side. I believe it is a debateable point even at the Opera as to whether these exercises are of real value in the dancing curriculum. I should mention that in the ballet classes all are dressed alike in white, but in the Rhythmic Class regulation swimming costume is worn. ${ }^{70}$

Who were the dancers Richardson might have seen? Among the 'grands sujets' the most important were Yvonne Daunt and Yvonne Franck. Both joined the company during the war years Daunt in 1918, Franck in 1917 - and were quickly cast in major roles of the eurhythmic repertoire. Of the two the English-born Daunt was probably the more interesting dancer: by 1920 she was 
already an étoile. Richardson spoke with admiration of her performance as the Spirit of Fire in Antar, noting her abandon and calling her a "brilliant exponent of barefoot dancing. ${ }^{71} \mathrm{~A}$. t'Serstevens, introducing an album of dry points by Louis Jou that depicted Daunt in various roles, referred to her as a 'Doric' dancer - 'grave, severe, and full of wisdom. ${ }^{72}$ In 1922, when she replaced Ida Rubinstein in the title role of La Tragédie de Salomé, Levinson (who thought that Daunt was miscast) described her as a 'queen of the Amazons':

She has ... a vigorous run that in three leaps allows her to cross the stage
on a diagonal. For her are the big bravura steps, those series of grand-scale
pirouettes; why not fouettés en tournant? Her training is solid; her tech-
nique honest. I like seeing her straight back as her foot lowers, its pointe
strictly vertical, the coup de pied prominent. For the developpés of the
adagio, aplomb is visibly wanting; the lineaments are perhaps too robust.
$\ldots$. But whatever is traveling or dynamic and greedy for space - that is for
her. $^{73}$

As Levinson's description makes clear, Daunt had strong classical training behind her. So, too, did Franck. The day before seeing Antar, Richardson actually watched the two of them take a private class with Madame Blanche d'Alessandri, a highly respected ballet teacher. 'These étoiles of the Opera are enthusiasts,' he wrote, 'and are not content with the classes at the Opera itself. The success and grace of Mlle. Daunt's barefoot work could now be traced to its origin - her strength and accuracy in the technique à la barre. ${ }^{74}$

Other dancers praised by the ballet brotherhood were Alice and Juliette Bourgat, who joined the Opéra in the early 1920s. Reviewing the 1922 revival of $L a$ Péri, Louis Laloy singled out Juliette for her 'vigorous bounds and expressive mime' in the title role, rechoreographed now by Staats. ${ }^{75}$ The same year, in Petite Suite, which Levinson dismissed as a 'trotting of bare feet all around the music,' it was her sister, Alice, who caught the critic's eye and actually caused him (as he put it) to 'applaud the adversary.' Four dancers were in a boat:

One of them, at the prow, looks ahead, fascinated; two others, pensive, observe the wake, their eyes lowered, while in the middle, a fourth, Mademoiselle [Alice] Bourgat, leans with a slow and curved movement over the invisible oar; the swaying of the skiff causes her supple body to undulate in its tunic. This imaginary crossing lasts some moments; under the baton of [Camille] Chevillard, a vision of the landscape seems to rise 


\section{FORGOTTEN INTERLUDE}

from the orchestra, fluid as a canvas of Corot. There is nothing that is not essential here, only four young women in Lamé tunics sitting on the bare stage hearing the music vibrate in themselves. Everything is suggested, nothing is realized. It is the spectator's imagination, stimulated by the magic bow, that creates. ${ }^{76}$

Vaillat praised both sisters for their contribution to Concerto. Since this is the only time he had anything good to say about any eurhythmic dance or dancer, his remarks are worth quoting, even if his mistakenly credits Montoliu's choreography to Alice Bourgat:

To [Sammartini's] exquisite music ... Mademoiselle Alice Bourgat has arranged a pas de deux, or more correctly, a pas for two dancers, herself and her sister Juliette, which they execute in an identical manner, each doubling as the shadow of the other, and both wearing the same costume a short fringed tunic of silk and a little Hindu diadem - designed by René Piot with that sure sense of orientalism that is his. Here was a composition based on eurhythmic methods, but one that was refined in personality and musicality: the arms, the legs, the entire body truly danced. ${ }^{77}$

Levinson, for his part, praised the 'decorative sense' revealed by Montoliu in Fresques: he especially liked how the choreographer distributed the groups of dancers onstage and the 'elegance with which he chained them in a kind of farandole. ${ }^{78}$ And for all Levinson's complaints, he felt that Montoliu's treatment of Sammartini's music was a 'revelation,' leaving the spectator 'free to recreate the spectacle in the inner theatre of his mind. ${ }^{.79}$

In a real sense, the best of the Opéra rythmiciennes were what might now be termed 'crossover' dancers. Although, officially, they belonged to the eurhythmic section, they also appeared in classical works, even if they did not necessarily dance on pointe (although, judging from photographs, Daunt sometimes $\operatorname{did}^{80}$ ). Thus, in Staats's ballet Frivolant (1922) and in his dances for the opera Padmâvatî (1923), both Daunt and Juliette Bourgat performed alongside leading Opéra classicists, as did Yvonne Franck in the choreographer's production of Cydalise et le chevre-pied (1923), and the two Bourgat sisters in his La Nuit ensorcelée (1923). All four dancers remained at the Opéra after the eurhythmic section was abolished in 1925, indicating the degree to which they had integrated themselves into the repertoire at large. Obviously, technical ability was a factor in this assimilation: all were proficient in classical work. However, this was not the only reason. 
Many roles of the period did not call for all the refinements of classical dancing. Some were character roles (in fact, Richardson, at one point, describes the choreography for Daunt as a Fury in Castor et Pollux as 'character work' ${ }^{81}$ ). Others demanded strong mimetic talents (throughout this period the Opéra made regular use of 'mimes' like Georges Wague); still others, that dancers, including classical dancers, perform barefoot, as in Les Troyens, the first time, as a shocked Vaillat noted, that this had happened at the Opéra. ${ }^{82}$ Moreover, apart from the principal dancers and soloists, it is unlikely that the standard of classical technique was very high, especially with regard to pointe work. In many photographs of the period, the appearance of the shoes worn by Opéra dancers suggests that they were only lightly blocked; in some instances, they also seem to lack a stiffening shank. What they resemble are the so-called 'demi-pointe shoes' manufactured today by Freeds and used chiefly by British dance students. Because of their construction, these slippers give very little support to the foot. Indeed, in such shoes, the multiple turns and jumped steps on pointe associated with the Italian bravura technique of the late nineteenth century are all but impossible to execute. ${ }^{83}$ This would tend to suggest that at the Opéra in the 1920s the difference between a crossover dancer like Daunt and the average ballet dancer was considerably less than might be expected.

More dramatic than the technical divisions between the two categories of dancers was the fact that several women of the eurhythmic section choreographed, even if they seldom had the opportunity of presenting their work at the Opéra. Daunt was among this group, and in 1921 she invited Richardson to a recital of dances at her studio before an audience of hand-picked guests:

Mlle. Daunt appeared with bare feet in soft Greek draperies, and gave a selection of about a dozen numbers. Here was something utterly different from the so-called Greek dance of to-day. Mlle. Daunt has conceived the idea that the technique which she has learnt à la barre is just as much the basis of bare foot dancing as it is of dancing sur les pointes in the conventional ballet. She put this to the test, and absolutely proved her point. Combining the soft arms which one associates with the neo-classic school, with the clean and accurate leg work of the operatic school, the result was a true poem. Her dances were both grandiose and humorous - her interpretation of the idea 'Poland in Chains and Poland Free,' in which she made use of a magnificent Chopin polonaise, was an excellent example of the former, in which her remarkable elevation was given free play. A dainty 'Menuet,' by 


\section{FORGOTTEN INTERLUDE}

Lully, was most expressively treated in humorous vein, and her art was so great that one forgot the incongruity of the menuet being danced with bare feet, but time prevented her making the necessary changes between each number. ${ }^{84}$

Levinson, by contrast, was so distressed by the recital that he devoted an entire column, 'Letter à Mlle ${ }^{* * *}$, de l'Opéra,' to exhorting the wayward Daunt to come to her senses, forget the 'outmoded childishness of Duncanism,' and accept what she was - 'a remarkable classical dancer.' 85

Yvonne Franck and Alice Bourgat were other members of the Opéra's eurhythmic section who choreographed as well as danced. Already in the mid-1920s, Franck had shown her work on a concert program shared with Daunt. ${ }^{86}$ Now, in 1927, she and Bourgat teamed up on a project using students from the Opéra school. 'One day,' writes Odette Joyeux in her charming memoir of life as a petit rat in the 1920s, 'I found my way to the eurhythmic studio. Although similar to ours, it was four times smaller; brown linoleum covered the floor. ... Two young women were talking to us. ... I didn't listen to what they were saying. I had vaguely understood that it was about a cachet, a fee. ${ }^{87}$ The women, it turned out, were Franck and Bourgat, and although they belonged 'to that other race' (as Joyeux thought of the rythmiciennes), they were going to stage a children's ballet. The title, the girls learned, was L'Eventail de Jeanne; it had music by Ravel, Jacques Ibert, Francis Poulenc, and a half-dozen other composers, and had been commissioned by Jeanne Dubost, a well-known hostess and music patron, for a private party. Joyeux seems to have been especially taken with Franck:

Mademoiselle Franck was very tall. Her slender silhouette carried with elegance the masculine suits that became her better than the suggestive frocks of courtesans. ... Under her pale blond hair, she offered an intelligent and ruddy face, and she wore a pearl necklace that I was astonished to see around her neck. She owned a beautiful convertible that she drove in an offhand way, and the luxurious modernism of her dressing room was surprising in a labyrinth where everything seemed to be of another age, another world. ${ }^{88}$

Joyeux's own dance, to Poulenc's 'Pastourelle,' pleased her immensely:

The music attacked; I waited a few measures, then jumped onstage. Straightaway, I became a little girl on a stroll, a capricious little girl who 
nonchalently hoisted herself on pointe, then, weary from the effort, dropped to the floor. The little girl sighed, stretched, ... played with her hat, and, without knowing why, recommenced her stroll, interspersed with leaps and pointes. The little girl whirled, then deliberately turned her back, and waddled off. Flirty and provocative, she returned, laughed, stuck out her tongue, and bounded out. ${ }^{89}$

Despite the resounding success of Jeanne, which, exceptionally, was taken into the repertoire of the Opéra although only in 1929, there was little in-house demand for these choreographers' services. The two continued to dance: Franck led the ballet (choreographed by Nijinska) in the 1926 and 1928 revivals of Gluck's Alceste and appeared in Nijinska's dances for the 1927 production of Philippe Gaubert's opera Naila, in which Bourgat also performed. At the premier of Jacques Ibert's opera Persée et Andromede (choreographed by Staats) in 1929, Bourgat was one of the Furies; at that of Maurice Emmanuel's opera Salamine (choreographed by Guerra) a few months later, Franck was the Danseuse Mariandyne. The following year the two appeared in the divertissement by Staats for Raoul Brunel's opera La Tentation de Saint Antoine. With Serge Lifar's appointment as the Opéra's principal ballet master late in 1929, however, their careers waned. After Tentation, their names disappear from the cast list of new productions (although both appeared in the 1931 revival of Padmâvatî), leading one to assume that they were either dropped from the company or pushed aside. The Opéra's eurhythmic adventure was over.

By 1930, however, the classe de rythmique itself was long gone. Five years before, adopting the tone of a necrologist, Levinson had announced to Comoedia readers-with what pleasure one can easily imagine-that the class was 'no more. ${ }^{.90}$ Its death marked a turning point in the 'reclassicization' of ballet, a call to order analogous to the conservative trend that appeared in French painting and music in the years after World War I. Just as Picasso had turned to Ingres and Stravinsky to a slew of composers past, so the Opéra began to take stock of its heritage. In 1924, Giselle returned to the repertoire after an absence of more than a half century; the following year, Soir de fête, a one-act work by Staats based on Delibes's music for La Source, invoked the forms and spirit of one of the Opéra's most popular ballets of the 1860 s and 1870s. Other works, from La Nuit ensorcelée (1923), by 
Staats to a libretto by Bakst and music by Chopin, to Le Triomphe de l'amour, a reconstruction of Lully's seventeenth-century ballet royal with choreography by Staats, looked resolutely backward. Well might Levinson write in 1925 that 'in one season, the Opéra ballet had won back much lost ground. ... The revivals of $L e$ Triomphe de l'Amour, Giselle, and La Source... signify a deliberate return to French tradition. ... The choice of works implies a recognition of the danse d'ecole as the basis for all true renewal. Embracing the beautiful cadences of classicism, the Opera rejects the idioms of Geneva and pidgen-French exoticism. ${ }^{91}$ So strong was the prevailing spirit of reaction that by 1925 even Nijinska, whose studio in post-revolutionary Kiev was linked in the general mind with Dalcroze experimentalism, ${ }^{92}$ insisted to Rouche that were she to teach at the Opéra, she would have nothing to do with eurhythmic dancers. ${ }^{93}$

The upshot of all this was to close off an important channel of dance experimentalism. By contrast with Germany and the United States, where elements of the Dalcroze system, like elements of Duncanism, Denishawn, and other movements, seeped into the richly textured fabric of Ausdruckstanz and modern dance, in France the experimentalist impulse failed either to penetrate the 'high' dance mainstream or to establish institutional alternatives to ballet, even if certain expressions of that impulsesuch as Djemil-Anik's exotic dances or Caryathis's avant-gardist ones-found a temporary berth on the music hall or concert stage. In a country where the production of art was totally centralized, where the State played a critical role in funding, and where the prestige conferred by a single institution was the coin of cultural acceptance, rejection by the Opéra of dance experimentalism was tantamount to willing its artistic death.

The disbanding of the Opéra's classe de rythmique in 1925 marked the beginning of the end of the experimentalist dance movement born in France in the first decade of the twentieth century from the combined influences of Duncanism, aestheticism, exoticism, eurhythmics, and the Ballets Russes. All had come together in the Thêâtre des Arts, not well perhaps, but in a way that proved sufficiently inspiring to turn several dancers into choreographers. Like Denishawn, the Théatre des Arts was a crucible of 'modern' dance talent, with the added distinction that, like the Ballets Russes, it was also a meeting ground for painters 
and composers of high order. When Jacques Rouché signed the order disbanding the troupe he had founded and defended at great cost, did he think back to the days when the new was an idea haloed with possibility, rather than a betrayal of the great tradition? When the exploration of techniques outside the danse d'école was not always condemned as a pastime for dilettantes? When works like Le Sacre du printemps shook the world? One would like to think he did, if only for a brief and passing moment.

\section{NOTES}

${ }^{1}$ The letters are filed in AJ13/1206 (II).

${ }^{2}$ Although named to the post in 1913, Rouché did not actually take office until 1915 because of the outbreak of World War I.

${ }^{3}$ See, for instance, Laloy's reviews of Léo Staats's version of the ballet Namouna ('La Musique,' La Grande Revue, 10 April 1908, pp. 608-11); Isadora Duncan ('La Musique,' La Grande Revue, 10 March 1909, pp. 184-8); Michel Fokine's ballet Le Pavillon d'Armide and Diaghilev's production of Alexander Borodin's opera Prince Igor ('La Musique,' La Grande Revue, 10 June 1909, pp. 607-10); Olga Preobrajenska's twoact version of Swan Lake at the London Hippodrome ('Le Ballet Russe à Londres,' La Grande Revue, 25 June 1910, pp. 864-6). For Matisse's 'Notes d'un peintre,' see La Grande Revue, 25 December 1908, pp. 731-47; for Emile Jaques-Dalcroze's 'Le Rythme au Théâtre,' La Grande Revue, 10 June 1910, pp. 539-50. Drawings by André Dunoyer de Segonzac accompanied the articles by Jaques-Dalcroze and Laloy (on Duncan), as well as the review by 'Toulet' of Diaghilev's 1910 season ('La Saison Russe à Paris,' La Grande Revue, 25 June 1910, pp. 867-73).

${ }^{4}$ Jacques Rouché, L'Art théâtral moderne (Paris: Cornely, 1910). A new edition appeared in 1924.

${ }^{5}$ For Piot's double career as a fresco painter and a designer, see Rodolph Rapetti's 'René Piot et le renouveau de la fresque,' and Martine Kahane's 'René Piot. Décors de théâtre,' in René Piot, 1866-1934, catalogue of an exhibition presented at the Musée d'Orsay, 26 February-27 May 1991.

6 'Mise en scène en crise, ou crise de mise en scène? Ce que j'ai fait au Théâtre des Arts. Ce que je fais et veux faire à l'Opéra,' Excelsior, n.d. Dossier d'artiste (Jacques Rouché), Bibliothèque de l'Opéra (Paris).

7 'Au Théâtre des Arts,' Comoedia Illustré, n.d. [1913], p. 655. Valentine Hugo Collection, Folder 25, Theatre Museum (London).

${ }^{8}$ Adélaïde, ou le Langage des fleurs was staged by François Ambrosini at the Opéra in 1917; La Tragédie de Salomé, by Nicolà Guerra, in 1919; La Péri, in a new version by Clustine for Anna Pavlova and Hubert Stowitts, in 1921; Istar, by Léo Staats, in 1924. Ma Mere l'Oye was produced at the Opéra in 1915.

${ }^{9}$ Of Hugard's contribution, and that of the ballet's other collaborators, Ravel had nothing but high praise. In a letter dated 1 February 1912, he wrote to Rouché: 'Your idea of mounting Ma Mère l'Oye enchanted me from the very beginning. For a long time, I have dreamed of writing a work for the Thêatre des Arts, which is the only theater in France today that brings us something new. However, I didn't dare hope for the total joy, so delightful to a composer, of seeing a work for the theater realized exactly as he had conceived it. The sumptuous and delicate harmony of Drésa's décor and costumes, whose theatrical logic is so fresh and personal, seem to me the most 


\section{FORGOTTEN INTERLUDE}

perfect commentary for my musical fantasy. Madame Hugard also proved to be an intelligent and fine collaborator, who took it upon herself to observe my tiniest instructions, and to realize them in an elegant and sensitive manner. All of my interpreters, including the children young and old, brought to their roles, large and small, an artistic integrity which delighted me and touched me profoundly... . Above all, dear Monsieur Rouché, I wish to express to you my pleasure at having met an artistic director whose constant concern is to respect the composer's ideas, while assisting him with the kind of intelligent advice that comes from a gentleman of taste' ( $A$ Ravel Reader: Correspondence, Articles, Interviews, ed. Arbie Orenstein [New York: Columbia University Press, 1990], pp. 129-30). At this time, Hugard was probably a dancer at the Opéra; in 1932, she was definitely on the payroll, although presumably as a teacher or régisseur. A fluent writer, she contributed an essay on the Opéra, 'Du Ballet classique,' to the volume Les Spectacles à travers les ages: musique, danse (Paris, Editions du Cygne, [1932]), pp. 193-212, and the preface to Gaspard Maillol's album of woodcuts of Opéra dancers, Danseuses (Paris: La Presse à Bras, [1932]). She is identified in the Maillol album as 'Jane Hugard de l'Opéra.'

${ }^{10}$ Namouna was produced at the Opéra in 1882 by Lucien Petipa; Favotte received its Paris premiere at the Opéra-Comique in 1899 in a choreography by Madame Mariquita.

${ }^{11}$ For photographs of her in La Danse prohibée, see Jean Codak, 'Sahary-Djeli: The "Mysterious One," Arabesque, November-December 1986, pp. 12-13, as well as the cover of the same issue.

${ }_{12}$ In 1913, for instance, he partnered Ariane Hugon, another Opéra dancer, in L'Amoureuse Leģon.

${ }^{13}$ Elise Jouhandeau, Joies et douleurs d'une belle excentrique: L'Altesse des hasards (Paris: Flammarion, 1954), pp. 13 and 19.

${ }_{14}$ André Levinson, La Danse d'aujourd'hui: Etudes, Notes, Portraits (Paris: Duchartre et Van Buggenhoudt, 1929), p. 456.

${ }^{15}$ A prolific writer, d'Udine was the author of Dissonance, a 'musical novel' (Paris: Editions du Courrier Musical, [1901-1902]); Gluck (Paris: Henri Laurens, 1906?); Qu'est-ce que la Danse?' (Paris: Henri Laurens, 1921), Qu'est-ce que la peinture et les autres arts plastiques? (Paris: Henri Laurens, 1929). Levinson, in La Danse d'aujourd'hui (p. 456), mentions two other titles - La Géométrie rythmique and L'Art et le Geste - neither of which I have been able to locate. D'Udine's real name was Albert Cozanet. I am indebted to Selma Odom for the information about Madame Barbey-Rouché.

${ }^{16}$ Jouhandeau, pp. 37 and 63. According to Caryathis, Staats had the other dancers in the cast compose their dances as well (p. 62).

17 Ibid., p. 101.

${ }^{18}$ Ibid., p. 227. Caryathis writes that Dullin managed to 'circumvent' Rouché, who engaged one of her friends instead.

19 Les Mémoires du Baron Mollet (Paris: Gallimard, 1963), p. 134. 'La Fête nègre,' which took place on 9 June 1919, was organized in tandem with Guillaume's 'Première Exposition d'art nègre et d'art océanien' at the Galerie Devambez, 10-31 May 1919. For Guillaume's various activities and the interest in African art among the Paris avantgarde, see Colette Giraudon, Les Arts à Paris chez Paul Guillaume 1918-1935, catalogue of an exhibition at the Musée de l'Orangerie, 14 September 1993-3 January 1994; Paul Guillaume, Les Ecrits de Paul Guillaume (Neuchâtel, Editions Ides et Calendes, 1993); Katia Samaltanos, Apollinaire: Catalyst for Primitivism, Picabia, and Duchamp (Ann Arbor, Mich.: UMI Research Press, 1984), especially chapter 2, 'Apollinaire and Primitivism.'

20 'Dans les Théâtres,' Le Gaulois, 2 April 1919, p. 4.

21 'Le Deuxième Spectacle de L'Oasis,' Comoedia, 25 June 1921. Valentine Hugo Collection, Folder 21, Theatre Museum (London).

${ }^{22}$ Ornella Volta, Satie et la danse (Paris: Editions Plume, 1992), pp. 45-50. 


\section{DANCE RESEARCH}

${ }^{23}$ Levinson, La Danse d'aujourd'hui, p. 469.

24 'Petites nouvelles théâtrales,' Comoedia, 16 December 1924, p. 2. A rehearsal photograph of Marcel Duchamp and Bronia Perlmutter, both nude, in a scene from CinéSketch is reproduced in Billy Klüver and Julie Martin, Kiki of Montparnasse: Artists and Lovers 1900-1930 (New York: Abrams, 1989), p. 137.

${ }^{25}$ André Arnyvelde, 'Ecoles de beauté,' Je sais tout-noel, n.d., pp. 612-613. Valentine Hugo Collection, Folder 49, Theatre Museum (London).

${ }^{26}$ Baron Mollet describes her as a 'black martiniquaise' (Les Mémoires du Baron Mollet, p. 134). However, photographs of the period indicate that she was of mixed blood, closer in coloring to café au lait , as Levinson described her 'beautiful . . . torso,' in a 1922 review ('Classicisme et exotisme', La Danse au Théâtre [Paris: Bloud \& Gay, 1924], p. 136). For photographs, see Levinson's La Danse d'aujourd'hui, pp. 299 and 306, and his Les Visages de la danse (Paris: Grasset, 1933), p. 247.

${ }^{27}$ Les Mémoires du Baron Mollet, p. 134.

${ }^{28}$ Levinson, La Danse au Théâtre, p. 136.

${ }^{29}$ In La Danse d'aujourd'hui, Levinson took Djemil to task for precisely this aspect of her work: 'Each of her exotic images has an atmospheric value. ... Their ports of call ... lead her through Shanghai, Angor-Wat, Delhi, and Baalbek, from the banks of the Sumida to the quays of Algiers; no sooner has she landed than she embarks for the perfumed Antilles... . I admire the intelligent will, the robust and beautiful body, the application of this individual artist, who searches relentlessly and continually adds to her creations. But I judge her method with extreme scepticism. . . Mademoiselle Djemil-Anik never ceases to hide her true face under masks rejected as soon as they are donned.... She gives herself over to pastiche, taking figurative monuments as points of departure. It is a mistake to seek counsel from stones; ... the conventions that determine their unchanging forms are utterly opposed to saltatory flight. ... The squatting Bodhisatva whose hieratic pose Mademoiselle Djemil reproduces at the beginning of one dance waits impatiently to return to his initial pose' (p. 307).

${ }^{30}$ René Piot, letter to Jacques Rouché, n.d. [1911]. Fonds Rouché, Th. des Arts, R8(4), Pièce 15(7), Bibliothèque de l'Opéra.

${ }^{31}$ René Piot, letter to Jacques Rouché, n.d. [1911?]. Fonds Rouché, Th. des Arts, R8(4), Pièce 15(9), Bibliothèque de l'Opéra.

${ }^{32}$ René Piot, letter to Jacques Rouché, n.d. [1912?]. Fonds Rouché, Th. des Arts, R8(4), Pièce 15(19), Bibliothèque de l'Opéra.

${ }^{33}$ René Piot, letter to Jacques Rouché, n.d. [1912?]. Fonds Rouché, Th. des Arts R8(4), Pièce 15(28), Bibliothèque de l'Opéra.

${ }^{34}$ Probably Teresina Negri, a dancer at the Opéra-Comique.

${ }^{35}$ René Piot, letter to Jacques Rouché, n.d. [1912?]. Fonds Rouché, Th. des Arts, R8(4), Pièce 15(24), Bibliothèque de l'Opéra.

${ }^{36}$ Although the Ballets Russes appeared at the Opéra in 1910 and 1914, most of its prewar seasons were given at the Théâtre du Châtelet and the Thêatre des ChampElysées.

37 'Courrier des théâtres,' Figaro, 19 September 1916, p. 4.

38 Irwin Spector, Rhythm and Life: The Work of Emile Faques-Dalcroze (Stuyvesant, N.Y.: Pendragon Press, [1990]), pp. 82, 224, and 230.

39 Jacques Rouché, 'La Danse en Russie (Impressions de voyage, hiver 1914),' in L'Art du Ballet des origines à nos jours (Paris: Editions de Tambourinaire, 1952), p. 100.

${ }^{40}$ For Honegger, see Spector, pp. 254-7; for Claudel, see his article 'Sur la Musique,' L'Opéra de Paris, no. 2 (October-November 1950), p. 4. Claudel wrote in part: 'I must confess that I have the greatest sympathy for the ideas of Jacques [sic] Dalcroze. Many years ago I attended a performance of Gluck's Orphée staged by him that was full of beauty. When a true school, as yet nonexistent, is established for the training of actors, the doctrine of Jacques [sic] Dalcroze will play a fundamental role in that undertaking. 


\section{FORGOTTEN INTERLUDE}

No step or gesture of the actor can be made without heeding a certain inner ear open to the bar.'

${ }^{41}$ See, for instance, Emile Jaques-Dalcroze, 'Le Rythme, les races et les tempéraments,' Mercure de France, 1 April 1919, pp. 408-22; 'Rythmiciennes,' Femina , 1 August 1919, pp. 27-30; Marius Boisson, 'Le Mouvement discipliné par le rythme des sons. M. Jaques-Dalcroze fait une démonstration de sa méthode intégrale d'eurythmie,' Comoedia, 13 February 1920, p. 1; Fernand Vandérem, 'Rythmique,' Femina, April 1920, pp. 2-6; W. Berteval, 'L'Enseignement de la Musique par la Méthode JacquesDalcroze: la gymnastique rythmique,' La Grande Revue, 1 July 1923, pp. 119-132. In 1921 and 1922 La Danse devoted a number of articles to teachers and choreographers associated with the eurhythmic movement. See, for example, Albert Jeanneret, 'La Rythmique,' La Danse, February 1921, n.p.; André Gliger, 'Jeanne Ronsay et la beauté nouvelle,' La Danse, August 1921, n.p.; D. Strohl, 'Danses gymnastiques,' La Danse, October 1921, n.p.; Paul-Sentenac, 'La Danseuse Romana et son école,' La Danse, October 1921, n.p.; F. d'Hautrelieu, 'Madame Geneviève Petit: Prêtresse du rythme,' La Danse, November 1921, n.p., and 'La Gymnastique harmonique,' La Danse, March 1922 , n.p. Albert Jeanneret was a composer and Dalcroze teacher who had studied at Hellerau; he was also the brother of the architect Le Corbusier (Spector, pp. 153n and 157).

${ }^{42}$ Léandre Vaillat, Ballets de l'Opéra de Paris (Ballets dans les opéras et nouveaux ballets) (Paris: Compagnie française des arts graphiques, 1947), p. 104.

${ }^{43}$ Marie Louise Morenté, a dancer in the corps de ballet, was among those few who opted to follow the 'cours de plastique.' Her letter, dated 2 December 1917, is filed with the other responses to Rouché's query, in AJ13/1206 (II), Archives Nationales.

${ }^{44}$ Rouché, 'La Danse en Russie,' p. 100.

${ }^{45}$ Olga Soutzo, letter to Jacques Rouché, 11 September [1917]. Blanche Guillemin was another who welcomed the 'stimulus' of discovering 'new tendencies in dance art,' while choosing to continue studying with Mauri (4 September 1917).

${ }^{46}$ Cyril W. Beaumont, Complete Book of Ballets (London: Putnam, 1937), p. 621.

${ }^{47}$ Jeanine Laugier, letter to Jacques Rouché, n.d. [September 1917]. In 1925, discussing a possible teaching position at the Opéra, Bronislava Nijinska insisted that 'classes from $1 \frac{1}{2}$ to 2 hours [were] essential' (Romola Nijinsky, letter to Jacques Rouché, 3 April 1925, AJ13/1213-1097, Archives Nationales).

48 Camille Bos, letter to Jacques Rouché, 5 September [1917].

${ }^{49}$ Jeanne Schwarz, letter to Jacques Rouché, 13 September [1917].

50 The list is in the Fonds Rouché, Pièce 106, Bibliothèque de l'Opéra. Those dancers who failed to respond to the questionnaire are so noted.

51 'Est-ce le grève à l'Opéra?' L'Humanité, 31 December 1919, p. 1.

${ }^{2}$ In 1921, George Cecil listed the rankings for readers of The Dancing Times as second quadrille, first quadrille, coryphées, petits sujets, grands sujets, premières danseuses, and étoiles (George Cecil, 'The Paris Opera Ballet,' The Dancing Times, January 1921, p. 335).

${ }^{53}$ Hugard, 'Du Ballet classique,' p. 208.

${ }^{54}$ Ibid.

${ }^{55}$ For most of the operas, see Vaillat, pp. 104-114; for the ballets and remaining operas, see the title entries in Stéphane Wolff's L'Opéra au Palais Garnier (1875-1962) (Paris: Slatkine, 1962).

${ }^{56}$ Vaillat, p. 107.

${ }^{57}$ Pasmanik also contributed to music journals, sometimes under the name of Pasmanik-Bespaloff. I am grateful to Selma Odom for the background information about her.

${ }^{58}$ Spector, p. 235. Howarth later worked with directors Fermin Gemier and Jacques Copeau. It would be interesting to know if Howarth is the 'Mademoiselle Jasmine' who played the role of Alkippé in Artemis troublée. 


\section{DANCE RESEARCH}

${ }^{59}$ Nicolà Guerra, letter to Jacques Rouché, 20 January 1918. Fonds Rouché, Pièce 166 (Guerra, Nicolà), Bibliothèque de l'Opéra.

${ }^{60}$ For the day-to-day repertoire during the period May-August 1922 (although not for the individual performances of the July ballet season), see the booking sheets (feuilles de location) in AJ13/1428, Archives Nationales.

61 'Théâtres,' Le Temps, 11 July 1922, p. 3.

${ }^{62}$ 'Théâtres,' Le Temps, 12 July 1922, p. 5.

63 'Théâtres,' Le Temps, 18 July 1922, p. 4.

${ }^{64}$ Obviously, neither Fokine nor Rubinstein was French. Guerra was Italian-born, as was Zambelli, although after nearly three decades on the Opéra stage, she had become something of a French national monument. Howarth was probably English; Pasmanik may have been Polish. The employment of foreign artists was an issue (along with demands for cost-of-living increases) in the strike of Opéra personnel that began in mid-October 1920 and lasted until the end of November. See, for instance, P.S., 'Le syndicalisme à l'Opéra,' Le Temps, 11 October 1920, p. 1.

${ }^{65}$ Spector, pp. 74, 196-7, 230, and 240. Spector states that Brooke was engaged before Jane Erb (pp. 205 and 261). However, there is no evidence supporting this claim.

${ }^{66}$ René Piot, letter to Jacques Rouché, n.d. [1921]. L.A.S. (Piot, René), 96, Bibliothèque de l'Opéra.

${ }^{67}$ Spector, pp. 156, 235, and 240.

${ }^{68}$ Vaillat, p. 107.

${ }^{69}$ Ivor Guest, in his history of ballet at the Opéra, devotes exactly one paragraph to the subject; Jacqueline Robinson, in her history of modern dance in France, ignores it entirely. See Guest, pp. 158-60, and Jacqueline Robinson, L'aventure de la danse moderne en France (1920-1970) (Paris: Editions Bougé, 1990).

70 'Sitter Out,' The Dancing Times, May 1921, p. 638.

71 'Sitter Out,' The Dancing Times, July 1921, p. 777.

72 A. t'Serstevens, $\boldsymbol{A}$ la Danseuse (Paris: Lapina, [1925]), n.p.

${ }^{73}$ Levinson, 'Le Répertoire: "La Tragédie de Salomé,"' La Danse au Théâtre, pp. 26-7.

74 'Sitter Out,' The Dancing Times, July 1921, pp. 777-8.

${ }^{75}$ Louis Laloy, 'La Musique: Quelques Réflexions sur le ballet moderne,' La Revue de Paris, 15 May 1922, p. 426.

${ }^{76}$ Levinson, “"En Bateau." Le Préjugé du rythme,' La Danse au théâtre, pp. 15-16.

77 Vaillat, p. 108.

${ }^{78}$ Levinson, La Danse d'aujourd'hui, p. 452.

79 Ibid., p. 456.

${ }^{80}$ On the inside cover of the May 1921 issue of The Dancing Times, Daunt is shown in costume for an unidentified ballet wearing pointe shoes. In a photograph for another unidentified ballet, this one in Orientalist style, she again appears in pointe shoes. Clipping File (Yvonne Daunt), Dance Collection, New York Public Library.

81 'Sitter Out,' The Dancing Times, March 1922, p. 502.

${ }^{82}$ Vaillat, p. 104.

${ }^{83}$ For photographs of various Opéra dancers, see Levinson's section on 'L'Esprit de la danse classique et le ballet d'Opéra' in La Danse d'aujourd'hui. I am indebted to Robert Greskovic for sharing his thoughts with me on the subject of pointe work.

84 'Sitter Out,' The Dancing Times, May 1921, p. 638.

${ }^{85}$ Levinson, 'Lettre à Mlle ***, de l'Opéra,' La Danse au théâtre, p. 72.

${ }^{86}$ For a review of this concert, see Levinson, La Danse d'aujourd'hui, p. 479.

${ }^{87}$ Odette Joyeux, Côté jardin: mémoires d'un rat (Paris: Gallimard, 1951), pp. 163-4.

${ }^{88}$ Ibid., pp. 164-6.

${ }^{89}$ Ibid., p. 169.

90 Levinson, 'La Danse. Epitaphe,' Comoedia, 21 September 1925, p. 3.

${ }^{91}$ Levinson, La Danse d'aujourd'hui, p. 201. 


\section{FORGOTTEN INTERLUDE}

${ }^{92}$ Myroslava M. Mudrak notes this on several occasions in her book The New Generation and Artistic Modernism in the Ukraine (Ann Arbor, Mich.: UMI Research Press, 1986).

${ }^{93}$ Romola Nijinsky, letter to Jacques Rouché, 3 April 1925. Archives Nationales, AJ13/1213-1097. 